\title{
Learning to Teach Writing to Engineers
}

\author{
Aviva Freedman \\ Natasha Artemeva \\ Carleton University
}

In this article, we describe an engineering writing course that was developed in response to the best pedagogic knowledge of the 80 s (relying on a version of the process approach to teaching writing). We analyse advantages and limitations of this course in light of modern theories of writing and present a new pedagogical model used to design an Engineering Communication Course. The pedagogy of this model is grounded in genre studies as well as notions of situated learning. The model is based on the premise that engineering communication courses closely linked to the engineering curriculum can provide settings that enable students to learm how to respond appropriately to different tasks by picking up the cues in their environment and how to make transitions to the practices of the workplace.

TEACHING WRTTING TO ENGINEERING STUDENTS POSES many problems. While engineers have recently begun to acknowledge and appreciate the role that writing plays in their work lives (e. g. Pinelli et al, 1996), engineering students are yet to be convinced. In fact, starting from high school, many have avoided and continue to avoid courses where writing is expected because they are confident that the career paths they have chosen demand numeracy but not literacy.

Further, while engineering professors (and more significantly, accreditation boards) affirm the importance of the teaching of writing, curricular planners still think of composition or communication as something to add on, or cross off. Writing courses tend to be squeezed into the interstices of engineering programs, where they will not interfere with the real business and teaching of the enterprise.

As to teaching materials, while writing textbooks for engineering students abound, very few seem to be congruent with the newer, richer understanding of composing and discourse structure that recent 
composition research and theory has brought to light. Of particular concern is the fact that, all too often, the writing elicited of student engineers is a curious hybrid-bearing little in common either with workplace engineering writing or with the university writing for engineering courses (Sloat, 1994; Artemeva and Fox, 1995).

The following account describes the odyssey of one of the co-authors who was seeking to find an approach to the teaching of writing to engineering students-an approach whose authenticity she could respect, and whose theoretic soundness she could approve. This account (perhaps inevitably) focuses on a misstep — the road taken and regretted; however, it was through taking this path (and as a consequence, understanding intimately its dangers) that a more appropriate road was discovered.

In the pages that follow, we first lay out the theoretic framework that seems most consonant with our experiences of discipline-specific discourse-our experiences as teachers, learners, and in the case of one author, a former practitioner in the field of engineering. We then go on to describe one attempt to teach engineering writing in an innovative way. Subsequent observation and experience proved this attempt to be limited. These limitations, however, turned out to be revealing: on the one hand, fleshing out and instantiating the theory; on the other, pointing to new possible models for teaching. We end by sketching briefly one such pedagogical model.

\section{Theoretic Background}

Notions of situated learning, set within the context of social constructionist genre theory, provide a useful basis for new approaches to teaching engineering writing in academia. In the next few paragraphs, we attempt a brief overview of such work.

\section{Social Constructionist Genre Theory}

Social constructionist genre theory based on the works of Bakhtin (1986) and Miller (1984) enables teachers and researchers to approach the problem of teaching engineering writing from a new perspective. Miller's definition of genre as social action in response to recurrent rhetorical situations (1984) has made it possible to consider genre as extending beyond regularities in textual features and to broaden our understanding of genre so that it encompasses regularities across composing practices (Paré and 
Smart, 1994) in response to rhetorical exigences. The textual regularities of texts are themselves seen to be traces, or symptoms of typified social actions, which actors are undertaking through language in response to recurring situations.

It goes without saying that learning how to understand and manipulate the genres of written communication in one's field is essential to professional success. The most powerful model for explaining genre knowledge and learning is found in the new field of psychology variously referred to as situated learning or practical cognition. To quote from Berkenkotter and Huckin (1995), "genre knowledge is...best conceptualized as a form of situated cognition embedded in disciplinary activities" (p. 3).

\section{Situated Learning}

Coincident with the development of genre theory, a new field in psychology has emerged: the field of situated cognition, or situated learning. Fundamental to this work is the perception of learning and knowing as social processes (Freedman and Adam, 1996). This understanding is based on the Vygotskian representation of higher mental functions in the individual as being derived from social life (Wertsch, 1991).

Central to the literature on situated cognition are the following notions:

- learning and knowing are context-specific: "there is no activity that is not situated" (Lave and Wenger, 1991, p. 33);

- learning is active and is accomplished through processes of co-participation; and

- cognition is socially shared.

This perspective focuses on performance, participation, and collaboration. It interprets learning as a social process during which learners first observe and then gradually learn through carefully orchestrated processes of co-participation (Lave and Wenger, 1991). Learning is located "in the process of co-participation, not in the heads of the individuals" (Hanks, 1991, p. 13). Theories of situated learning are focused on the relationship between learning and the social situations in which learning occurs; learning is seen as distributed among co-participants.

This conception of situated learning is particularly congruent with the social constructionist view of genre. In both, contexts are seen as activity systems, and in both, the role of local context is so powerful that the very possibility of portability has been questioned (Freedman, 1995). 
Freedman and Adam (1996) point to two distinct models of learning which have emerged from the literature on situated learning: Rogoff's "Guided Participation" (GP) and Lave and Wenger's "Legitimate Peripheral Participation" (LPP). As their common origin suggests, these two models share fundamental conceptions of learning; however, there are important differences. And it is these differences which cast particular light on important differences between learning in conventional university settings and learning in the workplace.

\section{Guided Participation}

Rogoff (1990) developed the notion of guided participation from the Vygotskian (1978) statement that what children can do in collaboration with a skilled adult today, they will be able to do alone tomorrow; in other words, learning takes place through processes of co-participation with an adult in a so-called zone of proximal development. For Rogoff, both guidance and participation are essential to a maturing child's apprenticeship in thinking.

This model accounts powerfully for the interactions between child and caretaker; it also describes most learning in school situations, including academic settings. However, as Freedman and Adam (1996) argue, when students move from the university context to the workplace context, they typically not only have to learn new genres but, more significantly, they need to learn new ways to learn. The basic orientation in Guided Participation (GP) is on learners and their learning. By contrast, in the workplace, newcomers and old-timers are involved in activities that have a purpose above and beyond the initiation of newcomers. The learning that takes place in workplace settings cannot be fully accounted for by the model of Guided Participation. The next section presents a different model of situated learning -one more appropriate to workplace learning.

\section{Legitimate Peripheral Participation}

Lave and Wenger (1991) introduce the term Legitimate Peripheral Participation (LPP) as an analytic model that is able to describe a range of social practices that can be "loosely referred to as apprenticeships" (Freedman, 1995, p. 12). As in Guided Participation, learning is seen as involving processes of co-participation. However, the goal of the activity is distinctly different in LPP. The goal of legitimate peripheral participation is action, the task itself, and its social outcome-not the process of learning 
(as in GP). Guided participation and legitimate peripheral participation, therefore, foreground different aspects of the learning process.

Specifically, LPP accounts for workplace apprenticeships where newcomers are trained by old-timers in the process of cooperative activity. The word "legitimate" refers to the fact that both newcomers and oldtimers are involved in authentic activities. Apprentices do not learn through dummy runs of invented tasks. The activity that they are engaged in is an authentic and legitimate part of the real-world task.

The term peripheral refers to the fact that the nature of the apprentice's involvement is attenuated to match her capacity. Newcomers are assigned that part of the undertaking which they are capable of. Gradually, with time, their involvement in the activity becomes more central. The model of LPP accounts for all workplace-based training situations, including internships and co-op programs.

\section{Comparing GP and LPP}

Table 1 (adapted from Freedman and Adam, 1996) summarises a range of differences between Guided Participation and Legitimate Peripheral Participation. In the paragraphs that follow, we examine these differences.

The nature of the task is distinct within these two modes of situated learning. Within the GP model, tasks that learners undertake are carefully planned and sequenced by their teachers: learners are able to solve problems " through material arrangements of...activities and responsibilities as well as through interpersonal communication,...observing and participating at a comfortable but slightly challenging level" (Rogoff, 1990, p. 18). In contrast, in the workplace the tasks are authentic and consequently cannot be purposefully sequenced.

A second point of comparison lies in the degree and kind of collaboration among near-peers. Engineering knowledge is constructed in rhetorical interaction within a professional community (Ede and Lunsford, 1992; Winsor, 1996). In the workplace, engineers rarely solve problems in pure solitude; rather, they work in teams, collaborate, and cooperate while working on a problem or a project (Dorman and Pruett, 1985; Burnett, 1996). University contexts typically evoke different patterns. While it is true that sometimes, in order to prepare engineering students for their future professional activity, instructors in technical communication classes create team projects that allow students to collaborate (Parker, 1995), typically the nature of the collaboration is quite different in school settings. 
Specifically, it is the teachers who orchestrate the team work and model the activities for the students. The differences in the nature of the collaboration are shaped profoundly by the differences in the goals of the activity and the nature of the evaluation as specified on the next page.

As to evaluation, in university courses (like all school settings), instructors simply have to assign an individual grade to each student. Even in a group project, teachers often mark students' reports as individually produced assignments because in a classroom context it is important to distinguish between work done by different students (Parker, 1995). In the workplace, where all team members are working on the same project, they all assume shared responsibility (Debs, 1991; Ede and Lansford, 1992) and the ownership of the product becomes corporate.

Table 1: Modes of Situated Learning

\begin{tabular}{|lll|}
\hline $\begin{array}{l}\text { Types of situated } \\
\text { learning }\end{array}$ & Guided Participation & $\begin{array}{l}\text { Legitimate Peripheral } \\
\text { Participation }\end{array}$ \\
\hline Primary theorists & Rogoff & Lave and Wenger \\
\hline Primary settings & University classroom & Workplace \\
\hline Focus of activity & Learning & $\begin{array}{l}\text { Product (though learning } \\
\text { always takes place) }\end{array}$ \\
\hline Participants & Teachers and learners & $\begin{array}{l}\text { Newcomers and } \\
\text { old-timers }\end{array}$ \\
\hline Nature of tasks & Sequenced & \begin{tabular}{l} 
Authentic; improvisatory \\
\hline Collaboration
\end{tabular} \\
$\begin{array}{l}\text { Peer collaboration; } \\
\text { modelling by teacher }\end{array}$ & $\begin{array}{l}\text { Division of labour } \\
\text { among all participants }\end{array}$ \\
\hline $\begin{array}{l}\text { Ownership of } \\
\text { product }\end{array}$ & $\begin{array}{l}\text { Individual (in terms } \\
\text { of evaluation) }\end{array}$ & $\begin{array}{l}\text { Corporate; shared } \\
\text { responsibility }\end{array}$ \\
\hline Audience & Teacher; one time & $\begin{array}{l}\text { Multiple (including } \\
\text { collaborators); extended } \\
\text { over time }\end{array}$ \\
\hline Evaluation & Of the learner & Of product \\
\hline
\end{tabular}


Finally, with respect to projects, a university assignment is usually a one-time endeavor addressed to a single audience (the instructor) whose goal is to teach certain skills and afterwards to evaluate the learner. In the workplace setting the transaction is fundamentally different. The draft and the final document are often read by many readers at different levels of seniority within and outside the organisation where the document has been produced, sometimes many years after the document has been written (Smart, 1993). The workplace audience is multiple and changing both in time and space.

\section{A Case Study of an Engineering Writing Course at a Canadian University}

Several years ago, one of the co-authors began teaching writing to engineering students within a formal university program. This teaching took place in the context of a somewhat unusual and innovative approach to the teaching of writing to engineering students-an approach that had been negotiated by the Writing Centre and the Engineering Faculty. The history of the writing program is as follows.

Some ten years ago, members of the Engineering Faculty approached the Writing Centre with a request for a diagnostic assessment that would help to identify students whose writing abilities were so limited as to impede successful completion of the program. ${ }^{1}$ (The notion was that those identified would subsequently receive tuition from the Writing Centre.) After considerable consultation and negotiation, the Writing Centre prepared the following proposal.

Instead of the kind of conventional diagnostic test of writing that the engineering faculty members originally had in mind, a more authentic writing task was envisioned-one which allowed for a more extended composing process, and one which involved a more realistic writing task. The end product was to be a design report, based on a real engineering problem. The process of producing this report was to be staged in such a way that students would have enough time to do research, to generate ideas, to go through several iterations, and, most important, to receive regular feedback from specifically designated tutors at the Writing Centre.

The writing task was to be a simulation of a real-world engineering problem in the form of an actual case study. Its topic was selected from engineering cases reported in journals, newspapers, or government documents. Students were provided with background literature and were

\footnotetext{
1. No Technical Communication courses were included in the Engineering curriculum.
} 
asked to produce a report that would, first, analyse and summarise the case history and, second, provide recommendations based on the conclusions of this analysis. In writing the report, they were asked to follow the format of the imagined "engineering firm" and to address an imagined manager (for the specification of a sample task, see Appendix A).

As the task became fully elaborated, the nature of the exercise changed. Rather than a diagnostic tool, the enterprise came to be seen as an opportunity to teach writing, and became entrenched in the curriculum as a prerequisite for graduation. This new writing program took the following form. Some time towards the end of the winter semester, firstyear students were introduced to the writing assignment. There was a preliminary lecture given by a staff member from the Writing Centre, focusing on the salient features of engineering writing. Then the precise assignment for that year was distributed.

All students entering second year Engineering were expected to submit a draft of the report during the summer term in order to receive feedback from a writing tutor. They were then required to submit the final copy of the report along with the draft and feedback sheets on the first day of classes in September. A range of tutorial options was available for students during the spring/summer terms: these included personal appointments with tutors at the Writing Centre as well as phone calls to the Summer Engineering Report Hot-line. In other words, the main pedagogical intervention for the summer report was the interaction between the student and the tutor who provided detailed feedback on the students' drafts.

\section{Learning From the Summer Engineering Report}

When it was first proposed, the design of this program seemed very attractive-certainly more so than the limited grammar-based model of testing and teaching that the engineering faculty originally had in mind. The organisation of the program allowed for a complete writing process, with ample opportunity for feedback during the process. Furthermore, the writing involved full-length texts that seemed to bear a relationship to the kind of writing that students would be expected to do in their future careers.

Notwithstanding these apparent strengths, over the years tutors experienced mounting frustration as the limitations of the task became apparent. While the assignment was based on and attempted to simulate a real-world engineering task, the simulation held little credibility. The students knew they were not engineers (they were first-year students); they 
knew that what they recommended would not be acted on and that the only real-world impact (and a very real one for them) was the Satisfactory or Unsatisfactory they would receive for their task. In other words, they understood very well the status of the task-as an obstacle they would have to overcome along the road to graduating from university as engineers.

Both genre theory and situated learning foreground the role of context -especially the tacitly understood and richly complicated context within which rhetorical transactions and social actions take place (Medway, 1993). While school assignments have often been criticised as "decontextualized," (Sloat, 1994; Artemeva and Fox, 1995; Meyer, 1996; Winsor, 1996) the reality is, as Lave and Wenger (1991) point out, that "schools themselves as social institutions and as places of learning constitute very specific contexts" (p. 40). To understand the nature of the limitations of the writing task set for the engineering students, it is important to acknowledge the actual context of student writing.

An added difficulty for the students arose from the rhetorical complexity of the task necessitated by the simulation. As Bakhtin (1986) states, "The choice of all language means is made by the speaker under varying degrees of influence from the addressee and his anticipated response" (p. 99). On the one hand, students were advised to imagine an overworked boss as their reader and to write with this scenario in mind. On the other hand, they knew that they were writing for an instructor or tutor who would "grade" their papers and who would respond according to the criteria appropriate in a university setting. The consequences of this 'dual sense of audience' (Sloat, 1994) were such that the tutor would often find two covering letters accompanying drafts of the summer engineering report: one addressed to the tutor, with directions on where to return the report, and the other addressed to the imagined "boss" or "manager" of the engineering firm specified in the assignment. More troubling was the fact that even the letter and report directed to the imagined employer were shaped fundamentally by the students' sense of what was required in this specialised university context, rather than what might be expected in a workplace. In other words, the rhetorical task was complicated in ways unappreciated by those originally setting the task.

The tutors knew too that they were not in a position to provide the kind of advice and guidance that colleagues or employees in the simulated workplace would be in a position to, and able to, offer. (This knowledge was particularly poignant for the author of this piece who had herself 
functioned as an engineer in a range of work settings.) Within the context of their teaching situations, they were totally removed from the complex political, social, and cultural dynamics of the workplace that was being simulated. Tutors, in providing feedback and evaluation, were guided by the criteria that were relevant to the university-based writing task. Of course, some of these criteria are relevant in both contexts: issues of spelling, punctuation, word-choice, syntactic form, etc. But the more complex, nuanced rhetorical issues are radically distinct (see discussion in Freedman, Smart and Adam, 1994.)

The form on the next page is a sample response form that all tutors were to use in responding to student writing. The left side includes all the standard questions and criteria that tutors were to respond to. On the right, there is space for tutors to comment. We can see on the sample draft form a typical set of comments.

Both the standard questions and the specific comments could easily be extracted from a typical freshman composition handbook. The criteria are general and specific to writing courses. The real issues of workplace writing are ignored. For example, there is no question raised about the amount of background knowledge that the reader is expected to have. Nor is there any mention of other possible readers, or their specific political or other agendas. Is it possible that the reader might find a certain set of recommendations threatening (because of an implied criticism of his earlier actions or inactions)? If so, are there ways of softening the language, being less (rather than more) direct, avoiding certain issues? And so on.

Furthermore, the teaching situation itself was limited. There were none of the richly contextualized interactions that allow for the sophisticated kind of learning that is possible in academic settings. Instead of a semester's (or year's) worth of lectures and readings, the discursive context was limited to one lecture, the assignment package, and a few (in the best scenario) interactions with tutors, often, by correspondence.

In the end, the writing elicited in this program was neither fish nor fowl. While the task was set in a university environment, the nature of the task was very different from the writing students undertook in other engineering classes. Further, as we have seen, the form of instructional guidance was highly impoverished in the sense that there were relatively few interactions and no ambient discursive context. 
Sample Draft Feedback Form with tutor's comments

\begin{tabular}{|c|c|c|}
\hline $\begin{array}{l}\text { Date } \\
\text { Name } \\
\text { by } \\
\text { Return Instructions }\end{array}$ & Topic & Reviewed \\
\hline Marker Response: YES (Y) & KEWHAT (S) & NO (N) \\
\hline $\begin{array}{l}\text { Does the report answer the question } \\
\text { raised by the topic? } \\
\text {-Are the ideas/recommendations developed? } \\
\text {-Does the report make sense? Is it logical? } \\
\text {-Is the report coherent and cohesive } \\
\text { overall? } \\
\text {-Is the report credible? }\end{array}$ & $\begin{array}{l}\text { Comr } \\
\text { Veryge } \\
\text { backgrc } \\
\text { difficul } \\
\text { No rec } \\
\text { own. }\end{array}$ & $\begin{array}{l}\text { nts on content } \\
\text { al. Not enough } \\
\text { d. Disorganized and } \\
\text { sufficiently follow. } \\
\text { mendations of your }\end{array}$ \\
\hline $\begin{array}{l}\text {-Does the report begin with a } \\
\text { statement of purpose? } \\
\text {-Is there sufficient context in the } \\
\text { statement? } \\
\text {-Does the report include a summary } \\
\text { of recommendations? } \\
\text {-Are the recommendations well focused? } \\
\text {-Are the sections organized logically? }\end{array}$ & $\begin{array}{l}\text { Comr } \\
\text { Add tal } \\
\text { your re } \\
\text { purpost } \\
\text { Recom }\end{array}$ & $\begin{array}{l}\text { of on organization } \\
\text { of contents. Start } \\
t \text { with a statement of } \\
\text { en put "Summary of } \\
\text { ndations" }\end{array}$ \\
\hline $\begin{array}{l}\text { Does the report use language that is } \\
\text { appropriate to writing in Engineering? } \\
\text { Does it avoid narrative style? } \\
\text {-Is the language concise? } \\
\text {-Is the word choice appropriate to } \\
\text { professional writing? } \\
\text { Is it relatively free of surface errors } \\
\text { (eg. spelling, grammar errors, etc.)? }\end{array}$ & $\begin{array}{l}\text { Comt } \\
\text { Use pa } \\
\text { persono } \\
\text { incomp } \\
\text { sentenc } \\
\text { paper). } \\
\text { (story- } \\
\text { retell th } \\
\text { handor } \\
\text { express }\end{array}$ & $\begin{array}{l}\text { nts on language } \\
\text { lel structure. Avoid } \\
\text { ronouns. Rephrase } \\
\text { e and inconsistent } \\
\text { (see comments in your } \\
\text { void narrative } \\
\text { ing) style. Do not } \\
\text { whole story from the } \\
\text { Avoid colloquial } \\
\text { is. }\end{array}$ \\
\hline $\begin{array}{l}\text {-Is the report easy to read? } \\
\text {-Is the typing clear and well presented? } \\
\text { Are there clearly defined sections marked } \\
\text { by sub-titles? } \\
\text {-Are diagrams/illustrations clearly identified } \\
\text { in the text? Are they useful? }\end{array}$ & $\begin{array}{l}\mathrm{S} \\
\mathrm{Y} \\
\mathrm{S} \\
\mathrm{N} / \mathrm{A}\end{array}$ & $\begin{array}{l}\text { nts on presentation } \\
\text { sections and } \\
\text { s. }\end{array}$ \\
\hline
\end{tabular}

At the same time, while the simulation was that of workplace writing, the actual task was far from real engineering writing--because of the radical difference in the rhetorical institutional situations (and exigence). In addition, the nature of the situated learning was a far cry from Legitimate 
Peripheral Participation-learning that emerges from collaborative work among near-peers and experts focusing on a real-world outcome. Hence the frustration of the tutors (and, undoubtedly, the students).

\section{Taking the Next Step: A New Communication Course}

As our discussion of the Summer Engineering Project implies, writing teachers in engineering programs are typically forced to be resourceful, creating possibilities for the kind of teaching that they believe to be appropriate in the context of small windows of opportunity opened to them by engineering curriculum planners whose main programmatic concerns lie elsewhere. In the Summer Engineering Project, a concern about testing for surface-level skills led to the development of a more extended writing program, with opportunities for feedback and response during the process of composing.

More recently, other changes to the engineering curriculum at this same university allowed for the development of a different kind of writing program-one that profited from the experience of the earlier project. Specifically, a few years ago, the provincial engineering accreditation board reviewed the engineering program as a whole and recommended, among other things, the institution of a more intensive and conventional writing and communication course for first- and second-year students, one that would be regularly slotted in the engineering curriculum.

The shape and staging of the new course proposed by the engineering faculty was far from ideal. The course instructor would have preferred an upper-level course where students could profit from both out-of-school work experience as well as more extensive in-school engineering knowledge. Nevertheless, accustomed professionally to being adaptive, she developed a new writing program that would allow for an approach to teaching that was consistent with more recent theories and that could build on the insights gleaned from the limitations she perceived in the Summer Engineering Project.

In designing the course, the instructor was most concerned to avoid the problems associated with simulations: the rhetorical confusions and the thinness of the discursive context. Consequently, since there was no possibility of building on the student-writers' actual experience in engineering workplace setting (these were, after all, first- and second-year students), the decision was made to link the new course to the actual engineering subject-matter courses. Communication classes were designed 
to build on, and to allow students to respond dialogically (Bakhtin) to the rich discursive contexts provided in the rest of the curriculum-with the discursive contexts established through lectures, readings, and oral interactions. The communication class thus was designed to provide students with the opportunity to perform these various tasks assigned in, and necessary for learning in, the engineering-content courses.

Specifically, in the new course, students are now asked to select one of the engineering courses they take concurrently with the Communication course and to focus on what they are learning and doing in this engineering course. The goal is for students to learn to perform the communicative tasks elicited in the engineering courses and to become more aware both of their learning processes as well as of communicative and rhetorical strategies appropriate within the discipline.

In order to enrich and build on the discursive context of the engineering course, one of the major assignments in the communication class is that students keep a journal on an electronic newsgroup, in which they comment on the subject-matter of the engineering course they are following, its assignments (labs, tutorials, exams) and other aspects. Students are also asked to comment on several journal entries made by their classmates every week. The course newsgroup allows students to write as engineering students, in their role as engineering students, without being forced to don roles that are unfamiliar to them (as in the simulations).

The instructor also participates in this newsgroup discussion, answering and asking questions, commenting on students' postings and providing assistance. In the course of the exchange of the written utterances in this electronic dialogue (in Bakhtinian terms), students gradually learn how to formulate questions appropriate to the discipline and how to offer disciplinary answers. From the perspective of genre studies, the newsgroup enriches the discursive context within which the students operate in their engineering courses and to which they are expected to respond as student writers. From the perspective of situated learning, the newsgroups allow for the kind of interaction among "near-peers" that is recognised as such a powerful tool for learning in communities of practice.

The learning of students is also shaped continuously by the kind of Guided Participation referred to earlier in this piece. The communication course is designed to include many opportunities for feedback. Thus, the time frame is organised so that students meet in small workshop groups for two hours a week, every week. One of the perceived problems in the 
Summer Project had to do with the relative thinness of the interactions between tutors and students. While the Summer Project allowed for and hoped to promote interaction over work-in-progress, in fact most students took limited advantage of these possibilities-because of the summer timetable and their geographic distance from the tutors. The new communication course allows for, even necessitates close cooperation both among the students and between students and the instructor.

In describing the course thus far, we have emphasised its focus on the genres of engineering school communication. At the same time, however, the course designer has been cognisant of the need, insofar as that was possible, to prepare students for workplace communication. Because of the necessary distance between the contexts of school and workplace (see Freedman, Adam and Smart 1994), it seems futile to assign writing appropriate for the workplace in the context of the university writing class. However, a consistent attempt has been made to elicit certain sets of practices that can be legitimately staged in the classroom and that are necessary for the workplace. These involve those collaborative strategies associated with Legitimate Peripheral Participation.

A major goal of the Communication course is to introduce students to just such collaborative strategies. Many activities in the course are performed in small groups; in organising such group activities, the instructor attempts to take into consideration the observations of other researchers who have studied the difficulties students face in making the transition to the workplace. Burnett (1996), for example, discusses a case of "a disfunctional" team of co-op students who failed their workplace project because they worked totally on their own. Burnett suggests that "a potentially more successful model [of a team project] might be based on...apprenticeship-students working with professionals rather than for them" (p. 154) (emphasis in the original).

For this reason, the collaborative work in this course involves team presentations. As opposed to most university work, the grade for the team presentation is shared by all participants. Just as in the workplace, students in the course are confronted with the reality that they will all share responsibility for the quality of their collaboratively produced product. In other words, in this respect at least, the collaboration has more in common with the apprenticeship form of situated learning (such as LPP) than with the school-based model. 
The interactions within the newsgroup also contribute to developing a communal collaborative ambience that is more like LPP. In both these respects, the course instructor has deliberately introduced practices that are geared towards encouraging the kind of learning practices more common in the workplace. This is not to say that the instructor is naive in believing that the classroom can simulate a real apprenticeship model of situated learning. In the end, the dominant model of learning, and teaching, is Guided Participation. And the instructor takes full advantages of the strength of this mode: the sequencing of activities that is permitted, the focus on learning, the close supervision of learners, etc. However, to the degree possible, certain practices are imported from the apprenticeship model, specifically in order to help ease the students' transition later to workplace practices.

\section{Conclusion}

To recapitulate our argument, teaching writing to student engineers has its own specialised set of constraints. As in other teaching situations, one must be alive to disciplinary knowledge and alert to classroom realities. However, to teach writing effectively to engineering students, one must also be responsive to other realities: one must cultivate the ability to improvise and adapt-and specifically to be creative in inventing opportunities for appropriate teaching in the context of less than hospitable curricular frameworks.

This article began by describing a teaching program that had been developed in response to the best pedagogic knowledge of the 1980s (relying on a version of the process approach to teaching writing) within the only niche in the engineering curriculum that had been then available.

More recently, just as disciplinary knowledge about the nature of discourse and the nature of learning was enhanced, a new opportunity for teaching presented itself-an opportunity which allowed for the implementation of a different kind of writing program. In designing that program its instructor tried to remain faithful both to the principles of newly evolved disciplinary knowledge as well as to the insights about teaching gleaned from the earlier experience.

The design of the new course is based on the premise that engineering communication courses closely linked to the engineering curriculum can provide settings that enable students to learn how to respond appropriately to different tasks by picking up the cues in their environments. 
The pedagogy of the course is grounded in genre studies as well as notions of situated learning. Supportive teaching is offered in the context of genuine discursive contexts, where students are guided collaboratively towards a mastery of the genres appropriate to their context. In the process, they are made aware of their learning, of their linguistic and rhetorical strategies, and of the nature of their responses to the rhetorical exigences of their situations. In the end, our expectation is that such experiences will equip students with the flexibility and sensitivity to the richness of context that is essential for any professional engineer in a rapidly changing modern workplace.

At the same time, while operating within the model of situated learning and especially that model which is most congruent with university teaching (GP), congenial strategies have been imported into the course, based on processes of situated learning more common in the workplace. Such practices have been taught to students as a way of easing their future transition to the practices of the workplace.

This teaching program, we know, is not an end-point. Inevitably its limitations will become apparent - in the light of classroom experience and in the light of new research and theory. This account, then, is not intended to be the last word. All we are doing is recording some steps on the journey.

\section{References}

Artemeva, N., \& Fox, J. (1995). Past, present, future: An overview of engineering communications courses in academia and WTS interventions in the first year of Engineering. This week at Carleton, $16(10), 5$.

Bakhtin, M.M. (1986). The problem of speech genres. In C. Emerson \& M. Holquist (Eds.), V. W. McGee (Trans.), Speech genres and other late essays (pp. 60-102). Austin, TX: University of Texas Press.

Berkenkotter, C., \& Huckin, T.N. (1995). Genre knowledge in disciplinary communication: Cognition/Culture/ Power. Hillsdale, NJ: Lawrence Erlbaum Associates. 
Burnett, R.E. (1996). "Some people weren't able to contribute anything but their technical knowledge": The anatomy of a dysfunctional team. In A.H. Duin \& C.J. Hansen (Eds.), Non-academic writing: Social theory and technology. Mahwah, NJ: Lawrence Erlbaum Associates.

Debs, M.B. (1991). Recent research on collaborative writing in industry. Technical Communication, 38(4), 476-484.

Dorman, W.W., \& Pruett, J.M. (1985). Engineering better writers: Why and how engineers can teach writing. Engineering Education, 75(7), 656-658.

Ede, L., \& Lunsford, A. (1992). Singular text/Plural authors: Perspectives on collaborative writing. Carbondale \& Edwardsville: Southern Illinois University Press.

Freedman, A. (1995, July). Genre studies, LPP and acquiring new genres. Paper presented at symposium. Discourse practices in workplace, school and academic settings: Recent research directions in writing, Melbourne, Australia.

Freedman, A., Smart, G., \& Adam, C. (1993). Wearing suits to class:

Simulating genres and simulations as genre. Written Communication, 11(2), 193-227.

Freedman, A., \& Adam, C. (1996). Learning to write professionally: "Situated learning" and the transition from university to professional discourse. Joumal of Business and Technical Communication, 10(4), 395427.

Hanks, W. (1991). Foreword. In J. Lave \& E. Wenger, Situated learning: Legitimate peripheral participation (pp.11-21). Cambridge: Cambridge University Press.

Lave, J., \& Wenger, E. (1991). Situated learning: Legitimate peripheral participation. Cambridge: Cambridge University Press.

Medway, P. (1993). Shifting relations: Science, technology and technoscience. Geelong, Australia: Deakin University.

Meyer, L. (1996). The contribution of genre theory to theme-based EAP: Navigating foreign fiords. TESL Canada Journal, 13(2), 33-45.

Miller, C. (1984). Genre as Social Action. Quarterly Journal of Speech, 70, 151167. 
Paré, A., \& Smart, G. (1994). Observing genres in action: Towards a research methodology. In A. Freedman \& P. Medway (Eds.), Genre and the new rhetoric (pp.146-154). London: Taylor \& Francis.

Parker, A. (1995). Evaluating collaborative projects and evaluation tools: Putting the pieces of the collaborative puzzle together. Technostyle, 12(1), 99-115.

Pinelli, T.E., Barclay, R.O., Keene, M.L., et al. (1996). From student to entry-level professional: Examining the role of language and written communications in the reaculturation of aerospace engineering students. Technical Communications, 43(3), 497.

Rogoff, B. (1990). Apprenticeship in thinking: Cognitive development in social context. New York, NY: Oxford University Press.

Sloat, E. A. (1994). Case studies of technical report writing development among students engineers. Unpublished doctoral thesis, McGill University, Montreal.

Smart, G. (1993). Genre as community invention: A central bank's response to its executives' expectations as readers. In R. Spilka (Ed.) Writing in the workplace: New research perspectives (pp. 124-140). Carbondale, IL: Southern Illinois University Press.

Vygotsky, L.S. (1978). Mind in society: The development of higher psychological processes. (M. Cole, V.J. Steiner, S. Scribner, \& E. Souberman, Eds.). Cambridge, MA: Harvard University Press.

Wertsch, J.V. (1991). Voices of the mind: $A$ sociocultural approach to mediated action. Cambridge, MA: Harvard University Press.

Winsor, D.A. (1996). Writing like an engineer: $A$ rhetorical education. Hillsdale, NY: Lawrence Erlbaum.

2. The Summer Writing Project will be marked independently by two markers. In order that comments may be written directly on the reports and marker objectivity maintained, two copies of the report are required. 


\section{Appendix A}

\section{Sample Assignment}

Summer Writing Project: Engineering 19-

All students entering the second year of the Engineering Program are required to submit the following writing project to the Engineering General Office upon registration, or at the latest by the first day of classes, September, 19-.

The project will consist of ALL of the following:

1. Two copies (original and photocopy) ${ }^{2}$ of a non-technical report based on one of the topics outlined below, written for the purpose of convincing a non-expert audience of your point of view. The focus of the report should be on recommendations and should include a selective summary of the relevant background information which led to the recommendation. Length: 6-8 pages, typed and double-spaced Estimate time required for completion: 10-15 hours

2. One (or more if desired) draft of the report. Estimated time required for completion: included above

3. A covering letter which would accompany the report when submitted to the client identified in the topic. The letter should include an overview of the major recommendations of the report and should be written in business letter format.

Estimated time required for completion: $40 \mathrm{~min}$.

4. An executive summary prepared for a superior, which briefly summarises the recommendations of the report. Estimated time required for completion 20 minutes.

5. A draft authorisation indicating that feedback was received on the work-in-progress, submitted before August 1, 19-. 
Students should not submit the Summer Writing report without draft approval from the Writing Centre.

Students who do not remain in town during the summer should send photocopies of their drafts by mail or fax and allow at least 2 weeks turnaround time. Any questions regrading the summer writing project should be directed to the Writing centre.

Topic: Recommendations regarding repair or replacement of a highway truss on the 401

You are working for the Highway Maintenance Department, Ministry of Transport in Toronto, and have been asked by your supervisor, Dr. Helen Sherman, to review the evidence collected by engineers in the field with regard to the collapse of a truss on highway 401 . Subsequent to your review, you will write a report, summarising your findings and explaining your recommendations regarding the replacement or repair of the truss. In addition, you should outline recommendations regarding other, similar trusses. The provincial transport commission in Quebec City has requested a copy of the report as well because many highways in Quebec have similar trusses.

An executive summary should be prepared for your supervisor:

Dr. Helen Sherman

Highway Maintenance Department

Ministry of Transport

Toronto, Ontario

Covering letter should be prepared for:

Mr. Michel Lapalme

Director

Highway Maintenance

Ministry of Transport

Quebec City, Quebec

(relevant articles and reports are included in the package) 